\title{
СОВРЕМЕННОЕ СОСТОЯНИЕ ВОЛЬФРАМОВОЙ ПРОМЫШЛЕННОСТИ РОССИИ
}

\author{
Хатьков Виталий Юрьевич ${ }^{12}$, \\ vitaliy@payler.com
Боярко Григорий Юрьевич², gub@tpu.ru \\ 1 ПАО «Газпром», \\ Россия, 196143, г. Санкт-Петербург, пл. Победы, 2. \\ 2 Национальный исследовательский Томский политехнический университет,
Россия, 634050, г. Томск, пр. Ленина, 30.
}

\begin{abstract}
Актуальность работы обусловлена необходимостью изучения проблем вольфрамовой промышленности России. Цель: изучение динамики товарных потоков (производства, импорта, экспорта, потребления) вольфрамовых продуктов (вольфрамовых концентратов, паравольфрамата аммония, вольфрамового ангидрита, ферровольфрама и металлического вольфрама); выработка рекомендаций по оптимизации товарооборота вольфрамовых продуктов.

Методы исследования: статистический, графический, логический.

Результаты. Россия обладает достаточной сырьевой базой для обеспечения вольфрамовой продукцией национальных потребителей и поставок на экспорт. Возможно возобновление добычных работ на Тырнаузском ГОКе в Кабардино-Балкарской Республике, Джидинском вольфрамо-молибденовом комбинате в Республике Бурятия и осуществление нового добывающего проекта на Агылкинском месторождении в Республике Саха (Якутия). Российский рынок вольфрамового сырья подвержен резким колебаниям объемов производства, экспорта и импорта, осложняемым несогласованностью интересов добывающих, перерабатывающих и потребляющих вольфрамовую продукцию предприятий. Кроме сокращения добычи вольфрамового сырья вследствие остановки убыточных выработанных рудников возникли встречные импортно-экспортные потоки вольфрамовых концентратов и ферровольфрама, создавая искусственную импортозависимость для их потребителей. Для «оздоровления» российской вольфрамовой промышленности необходима консолидация предприятий, добывающих вольфрамовое сырье, и перерабатывающих предприятий в вертикально интегрированные холдинги с привлечением состоятельных инвесторов, реанимация закрытых добывающих производств на крупных и уникальных месторождениях с бедными рудами на основе улучшения технологий обогащения, поиски и освоение новых месторождений с богатыми вольфрамовыми рудами.
\end{abstract}

\section{Ключевые слова:}

Вольфрамовая промышленность России, вольфрамовые концентраты, паравольфрамат аммония, вольфрамовый ангидрид, ферровольфрам, вольфрам металлический, искусственная импортозависимость.

\section{Введение}

Вольфрал - металл, используемый в твердых и жаропрочных материалах в качестве легирующей добавки в производстве сталей, кислотоупорных и специальных сплавов, в электротехнике, в химической промышленности [1]. Исходным сырьем для производства вольфрама являются вольфрамитовые и шеелитовые концентраты, производящиеся на собственно вольфрамовых, а также комплексных (молибден-вольфрамовых, вольфрамоловянных и др.) месторождениях [2-4]. Товарными вольфрамовыми продуктами являются сырьевые вольфраловые руды и кониентраты, промежуточные продукты: паравольррамат алмония, вольфраловый ангидрид и ферровольфрал, и конечные продукты: металлический вольфрал $u$ карбид вольфрала.

Особенностями рынка вольфрамовых продуктов является давление естественной монополии Китая, производящего до 80 \% мирового предложения вольфрамовых продуктов, и неустойчивость предложения вольфрамового сырья остальными добывающими производителями при нестабильности цен на вольфрамовые продукты $[1,5-13]$. Сложное положение сложилось и в российской вольфрамовой промышленности. Если
СССР в период плановой экономики являлся импортером вольфрамового концентрата и экспортером вольфрамовых продуктов, то в настоящее время российская вольфрамовая промышленность, добывая вольфрамовый концентрат в десять раз меньше Китая, стала мировым лидером его экспорта. В то же время российские потребители вольфрамового сырья периодически импортируют вольфрамовый концентрат, а также товарные вольфрамовые продукты. Сложившаяся ситуация отсутствия эффективной кооперации производителей и потребителей вольфрамового сырья и их товарных продуктов на российском рынке требует своего решения.

\section{Методы исследований}

С целью изучения российского рынка вольфрамовых продуктов были обработаны данные по движению товарных потоков вольфрамовых продуктов за 1996-2017 гг., по динамике мировых цен на вольфрамовые продукты и цен российского импорта и экспорта. Источники информации: бюллетени и обзоры Геологической службы США и Британии $[14,15]$, Государственные доклады Федерального агентства недропользования России [16], статистические данные Таможенных служб России [17] и 
Казахстана [18], обзоры маркетинговых компаний $[19,20]$. Недостаточно полна информация по производству и экспорту ферротитана, поэтому его национальное потребление можно оценивать лишь приблизительно. Практически полностью отсутствует информация по объемам выпуска российскими предприятиями карбида вольфрама, поэтому этот продукт в анализе не участвует. Цены на вольфрамовый концентрат приведены к стоимости 1 метрической тонны $\mathrm{WO}_{3}$. Диаграммы показателей построены в интервалах времени, по которым собраны наиболее достоверные данные с минимальной погрешностью баланса. В качестве индикатора мировых цен международной торговли выбраны импортные цены для самого емкого рынка вольфрамовых продуктов - США. Уровень импортозависимости оценивался как доля импортных поставок в объемах потребления российских перерабатывающих предприятий, уровень экспортоориентированности - как доля экспортных поставок от объемов добычи российских предприятий.

\section{Состояние вольфрамодобывающей промышленности России}

Ситуация по обеспечению промышленности России вольфрамовым сырьем является противо- речивой. На территории России имеются действующие предприятия по добыче и переработке вольфрамового сырья, а также производство вольфрамовых продуктов, но их внутренний рынок сбыта весьма ограничен, а на мировом рынке торговая политика вольфрамосодержащими материалами определяется монопольным давлением китайских производителей, осуществляющих до 65-70 \% мирового производства вольфрама [1].

Добычу вольфрамовых руд и концентратов осуществляют (рис. 1):

- ОАО «Приморский ГОК» (ОАО «ГК «АИР» на месторождении Восток-2 (среднее содержание $\mathrm{WO}_{3}>1 \%$ ), Приморский край;

- 000 «Лермонтовский ГОК» на Лермонтовском месторождении ( $\mathrm{WO}_{3}>1$ \%), Приморский край;

- $3 \mathrm{AO}$ «Новоорловский ГОК» на Спокойнинском месторождении $\left(\mathrm{WO}_{3}=0,224 \%\right)$, Забайкальский край;

- 000 «Старательская артель «Кварц»» на БомГрохонском месторождении $\left(\mathrm{WO}_{3}=0,9 \%\right)$, Забайкальский край.

Попутную добычу вольфрамового концентрата осуществляет 000 «Правоурмийское» на одноименном оловянном месторождении (Хабаровский край) и $3 А О$ «Закаменск» (дочернее предприятие

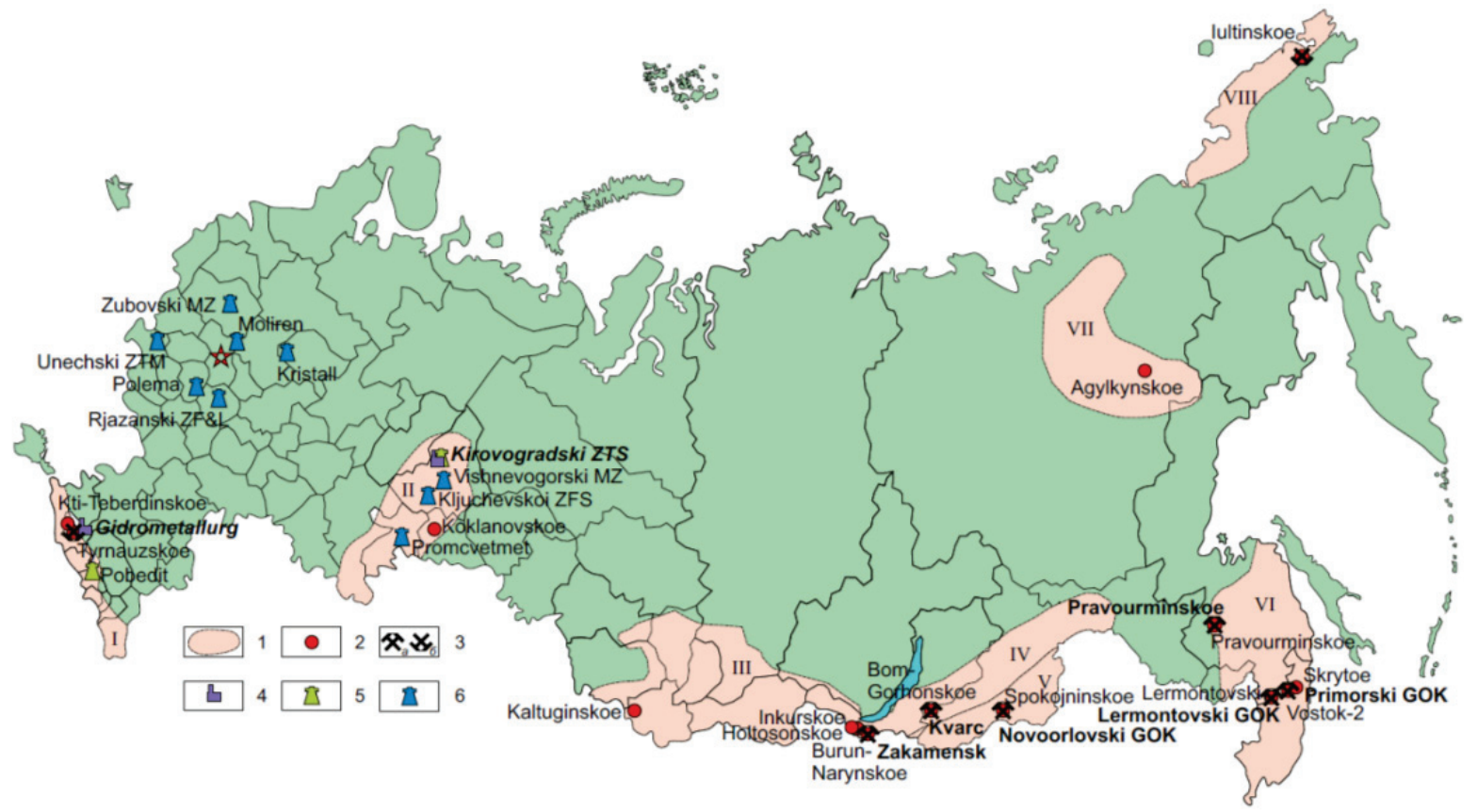

Pис. 1. Вольфрамоносные провинции и предприятия, добывающие, перерабатывающие и производящие вольфрамовую продукцию: 1 вольфралоносные провинции (I - Северо-Кавказская, II - Южно-Средне-Уральская, III - Алтае-Саянская, IV - Селенгино-Становая, V - Монголо-Забайкальская, VI - Ханкайско-Охотская, VII - Яно-Кольлская, VIII - Чукотская); 2 - месторождения вольфрама; 3 - предприятия, добывающие вольфрамовое сырье (а - действующие, б - законсервированные); 4 - гидрометаллургические предприятия, перерабатывающие вольфрамовое сырье, с производством паравольфрамата аммония и вольфрамового ангидрита; 5 - предприятия с производством вольфрама металлического и карбида вольфрама; 6 - ферросплавные заводы, производящие ферровольфрам

Fig. 1. Tungsten bearing provinces and enterprises producing, processing and manufacturing tungsten products; 1 - tungsten bearing provinces (I - Severo-Kavkazskaya, II - Yuuzhno-Sredne-Uralskaya, III - Altae-Sayanskaya, IV - Selengino-Stanovaya, V - Mongolo-Zabaykalskaya, VI - Khankaysko-Okhotskaya, VII - Yano-Kolymskaya, VIII - Chukotskaya); 2 - tungsten deposits; 3 - enterprises producing tungsten raw materials ( $a$-active, $b$ - canned); 4 - hydrometallurgical enterprises processing tungsten raw materials, with the production of ammonium paratungstate and tungsten anhydrite; 5 - enterprises with the production of tungsten metal and tungsten carbide; 6 - ferroalloy plants producing ferrotungsten 


\section{Вольфрамовый концентрат Tungsten concentrate}
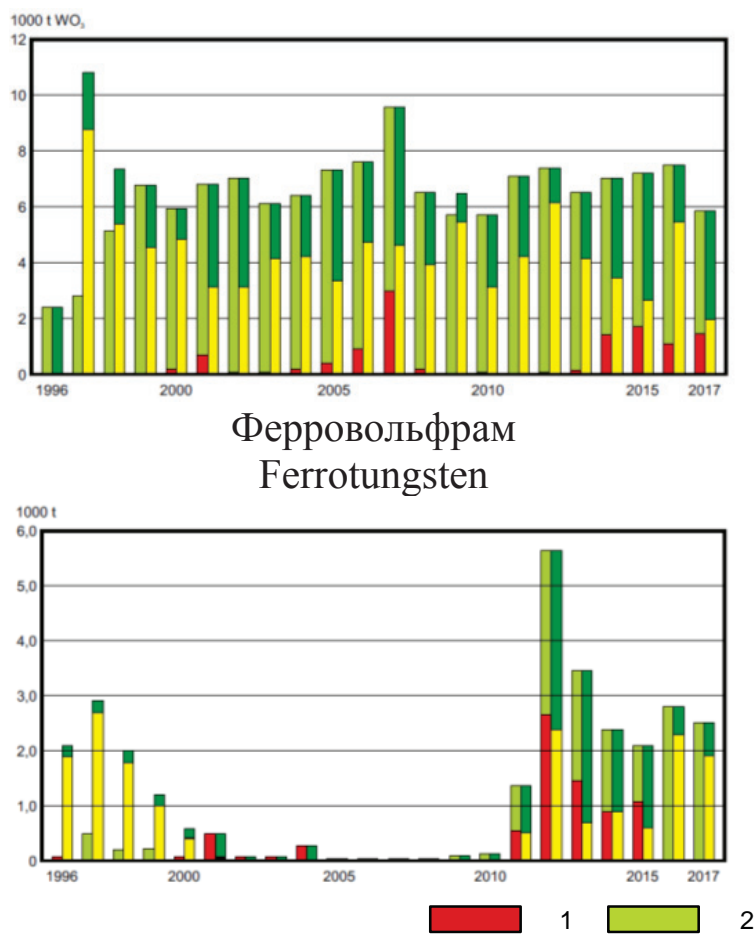

Паравольфрамат аммония+вольфрамовый ангидрит

Ammonium paratungstate+tungsten anhydrite

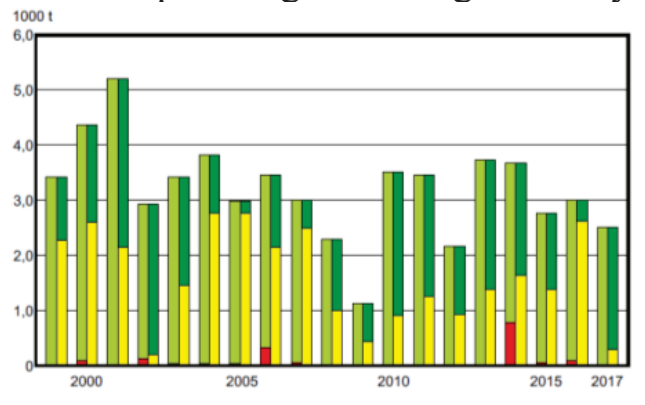

Вольфрам металлический Metal tungsten

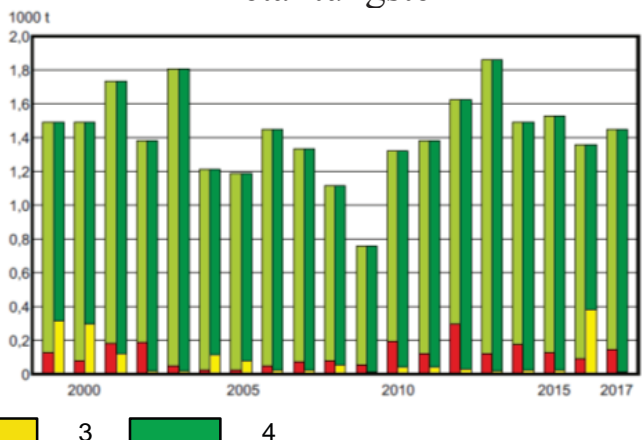

Рис. 2. Динамика баланса рынков вольфрамовых продуктов России за 1996-2017 г2. Составлено по обобщенныли данныл [14-20]. 1 - илпорт, 2 - производство, 3 - экспорт, 4 - нетто-потребление

Fig. 2. Dynamics of balance of Russian tungsten products markets for 1996-2017. Compiled from generalized data [14-20]. 1 - import, 2 - production, 3 - export, 4 - net consumption

000 «Группа Акрополь») из отвалов закрытого в 90-е гг. Джидинского ГОКа на Бурун-Нарынском месторождении (Республика Бурятия).

В 90-е гг. была остановлена добыча вольфрамового сырья на Иультинском ГОКе в Чукотском АО и Тырнаузском вольфрамо-молибденовом комбинате в Республике Кабардино-Балкария.

На рис. 2 приведен баланс внутреннего рынка вольфрамового концентрата РФ в 1996-2017 гг.

Добыча вольфрамовых руд относительно стабильна и находится на уровне 5,5-7,0 тыс. т/год. Значительная часть (45-90 \%) произведенного вольфрамовых концентратов идет на экспорт. В условиях, когда мировая добыча вольфрама увеличивается с темпами $+7,6$ \% /год, доля предложения вольфрамовых концентратов из России падает с $12,1 \%$ в 2000 г. до $2,6 \%$ в 2017 г. Рост добычи вольфрама в Китае (+8,8 \%/год и $83 \%$ мировой добычи вольфрамового концентрата в 2017 г.) и Вьетнаме (+35,4\% /год и 7,5 \% в 2017 г.), а также появление новых участников добычи вольфрама (в Британии, Испании, Австралии, Руанде, Бурунди, Зимбабве) осложняет позиции России на рынке предложения вольфрамового сырья.

Нетто-потребление вольфрамовых руд колеблется от 1 до 5 тыс. т/год. Среднегодовое изменение потребления вольррамового концентрата ра- стет $-+9,1 \%$, как и реализации (потребление+экспорт) $-+4,3 \% /$ год.

Для обеспечения работы российские потребители вынуждены периодически (2006-2007 и 2014-2017 гг.) приобретать по импорту крупные партии вольфрамового сырья - до 3 тыс. т/год на сумму до 68 млн \$США/год.

Вольфрамовое сырье поступает из Южной Кореи, Японии, Нидерландов, Канады, Вьетнама, и других стран (рис. 3). Экспортируется же оно в Китай, Южную Корею, Австрию, Японию и Нидерланды, образуя, в том числе, встречные импортноэкспортные потоки.

Динамика цен мировой торговли на вольфрамовые руды и концентраты (рис. 4) имеет следующие временные тренды: стабильный уровень 2600-3800 \$США/т в период 1996-2004 гг., подъем цен в 2005-2006 гг. и стабилизация на уровне 12400-13400 \$CША/т в 2006-2010 гг., новый подъем с историческим максимумом в 23300 \$США/т в 2012 г. и плавное падение до 17900 \$CША/ т в 2015 г. (в 2017 г. 18900 \$США/т). Цены российского импорта и экспорта на 20-40\% ниже мировых, причем если изменения экспортных цен конформны мировым, то импортные цены имеют дополнительно дисгармонию резких скачков. 
Экспорт/Export

Вольфрамовый концентрат/Tungsten concentrate

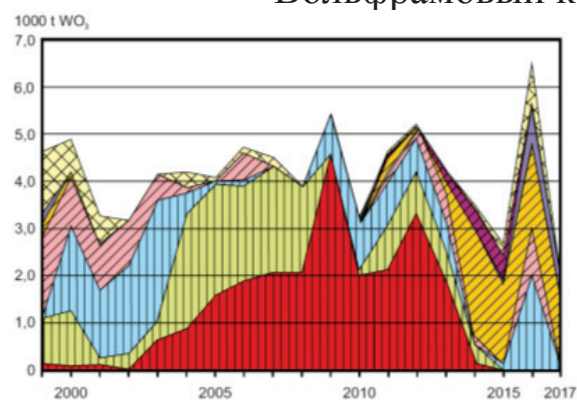

Паравольфрамат аммония+вольфрамовый ангидрит

Ammonium paratungstate+tungsten anhydrite
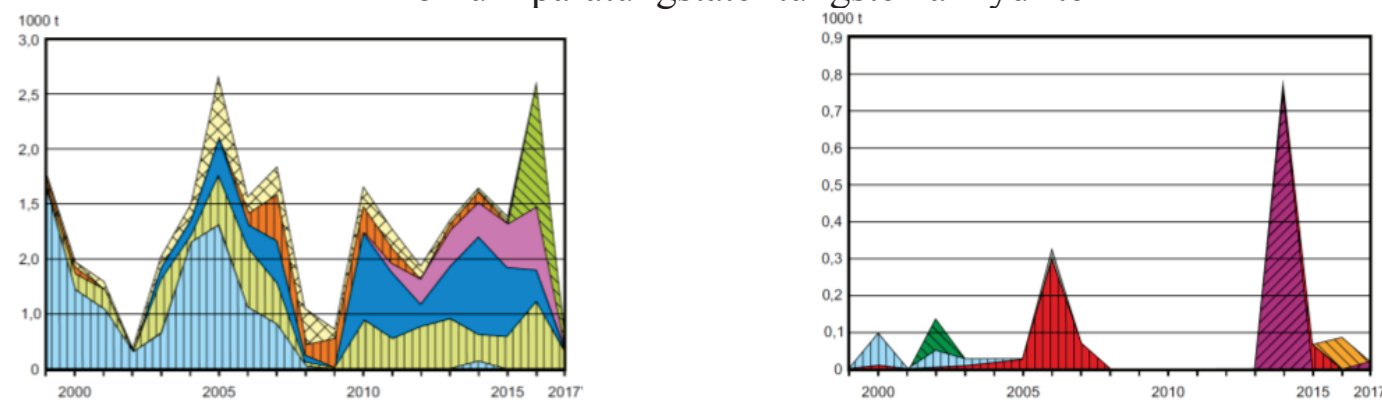

Ферровольфрам/Ferrotungsten
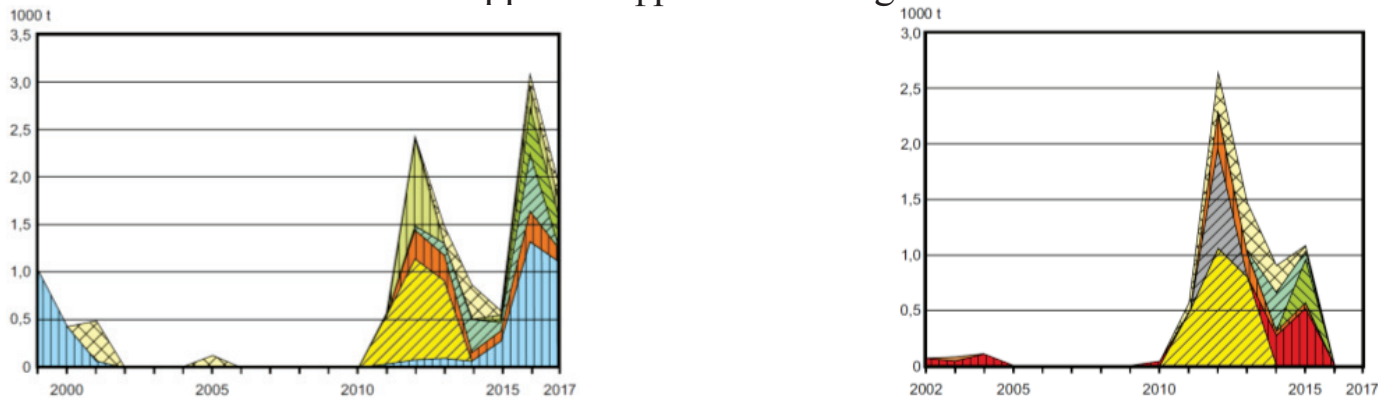

Вольфрам металлический/Metal tungsten
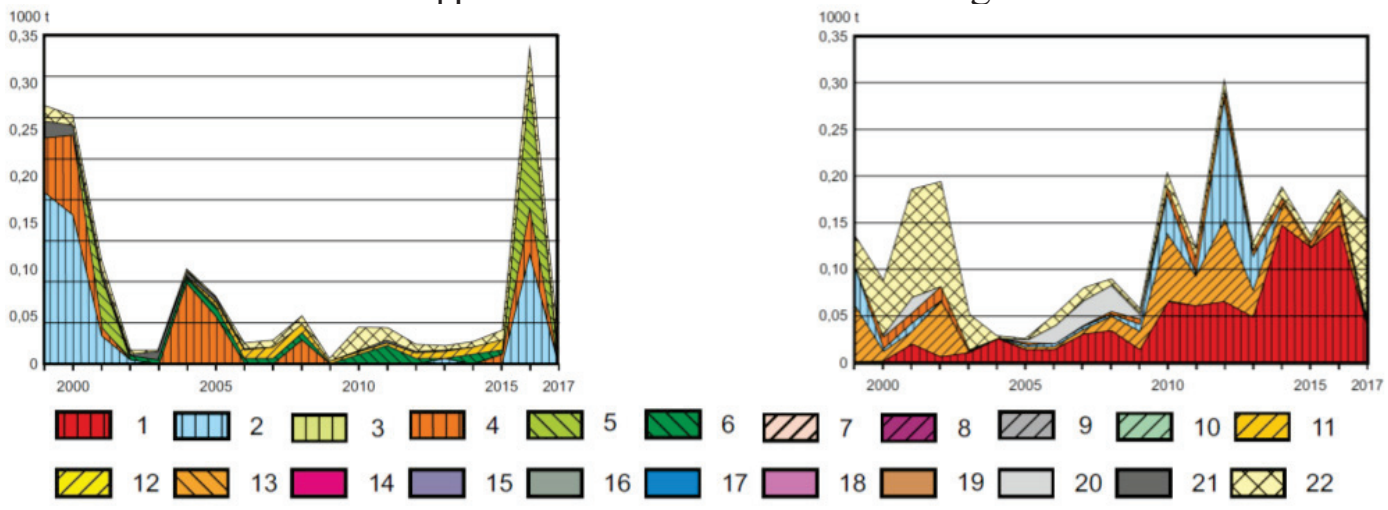

Рис. 3. Динамика объемов импорта и экспорта вольфрамовых продуктов по странам-партнерам за 1999-2017 г2. Составлено по обобщенным данным [14-20]. 1 - Китай, 2 - Нидерланды, 3 - Австрия, 4 - Германия, 5 - Эстония, 6 - США, 7 - Япония, 8 - Вьетнам, 9 - Латвия, 10 - Канада, 11 - Южная Корея, 12 - Казахстан, 13 - Узбекистан, 14 - Монголия, 15 - Сингапур, 16 - Британия, 17 - Чехия, 18 - Франция, 19 - Бразилия, 20 - Финляндия, 21 - Украина, 22 - другие страны

Fig. 3. Dynamics of import and export volumes of tungsten products by partner countries for 1999-2017. Compiled from generalized data [14-20]. 1 - China, 2 - Netherlands, 3 - Austria, 4 - Germany, 5 - Estonia, 6 - US, 7 - Japan, 8 - Vietnam, 9 - Latvia, 10 - Canada, 11 - Republic of Korea, 12 - Kazakhstan, 13 - Uzbekistan, 14 - Mongolia, 15 - Singapore, 16 - UK, 17 - Czech Republic, 18 - France, 19 - Brazil, 20 - Finland, 21 - Ukraine, 22 - other countries 
Вольфрамовый концентрат Tungsten concentrate

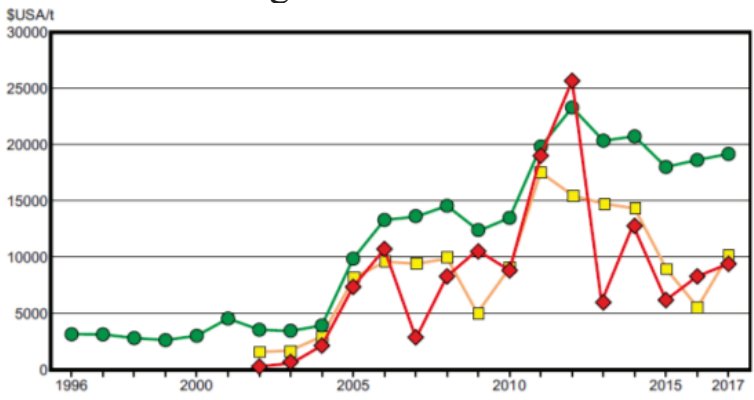

Вольфрамовый ангидрит

Tungsten anhydrite

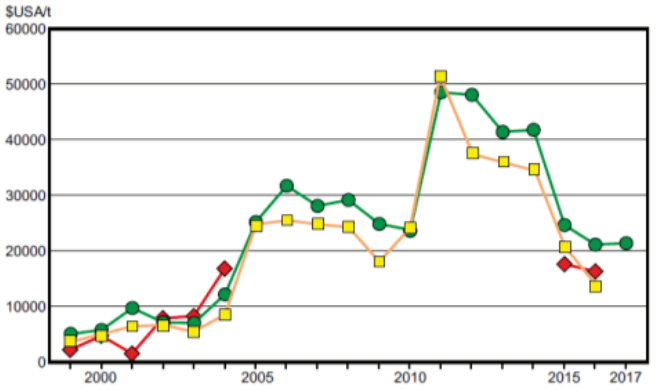

Вольфрам металлический Metal tungsten

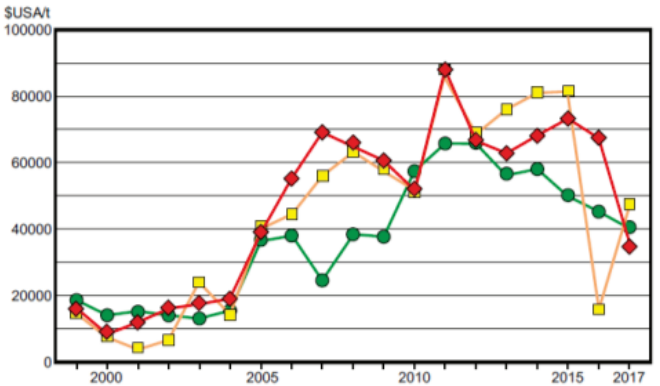

В период 1997-2017 гг. доля экспорта вольфрамовых концентратов от национальной добычи превышает 60 \% , т. е. этот товарный продукт является экспортоориентированныл (рис. 5). Одной из причин значительного экспорта вольфрамового концентрата являлось расположение добывающих предприятий на Дальнем Востоке, а потребляющих его - в европейской части России, когда ставки железнодорожного тарифа для руд цветных металлов являются самыми высокими среди всех перевозимых товарных групп. В результате этого становится выгодно экспортировать вольфрамовый концентрат, даже с учетом расходов на вывозную таможенную пошлину (10\% от стоимости). В то же время в 2006-2007 и 2014-2017 гг. доля импорта вольфрамовых концентратов превышает $25 \%$ от производства (в 2016 г. - свыше $100 \%$ ). По сути дела, возникает искусственная импортозависимость потребителей вольфрамовых концентратов ввиду недостатка поставок с национальных добывающих предприятий, отправляющих большую часть своей продукции на экспорт.
Паравольфрамат аммония Ammonium paratungstate

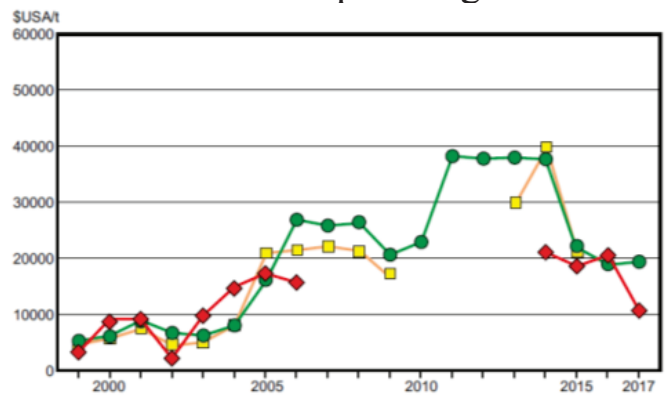

Ферровольфрам/Ferrotungsten

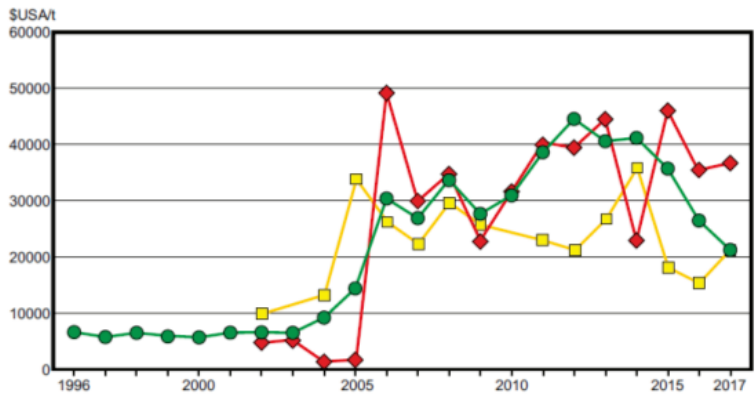

Puс. 4. Динамика цен на вольфрамовые продукты за 1996-2017 22. Составлено по обобщенным данным [14-20]. Круг импорт в США, ромб - импорт в Россию, квадрат - экспорт из России

Fig. 4. Dynamics of prices for tungsten products for 1996-2017. Compiled from generalized data [14-20]. Circle - import to USA, rhombus - import to Russia, rectangle - export from Russia

\section{Состояние промышленности}

\section{по переработке вольфрамового сырья в России}

Паравольфралат аллония или «желтый ангидрит вольфрама» $\left(\mathrm{NH}_{4}\left[\mathrm{WO}_{2} \mathrm{~F}_{3}\right]\right)$ и вольфрамовый "синий» ангидрит $\left(\mathrm{WO}_{3}\right)$ являются исходным сырьем для производства ферровольфрама и металлического вольфрама, а также других соединений вольфрама.

Производство паравольфрамата аммония (ПВА) и вольфрамового ангидрита (BА) осуществляют следующие предприятия (рис. 1):

- ОАО «Гидрометаллург», г. Нальчик, Кабардино-Балкарская Республика;

- ОАО «Кировградский завод твердых сплавов», г. Кировоград, Свердловская область.

Динамика рынка суммы ПВА+ВА показана на рис. 2. Наблюдается очевидная экспортная направленность производимых этих промежуточных вольфрамовых продуктов.

Производство суммы ПВА+ВА во времени крайне неравномерно - повышение до 5,2 тыс. т в 2001 г. и падение до 1,1 тыс. т в 2009 г. 
Вольфрамовый концентрат

Tungsten concentrate

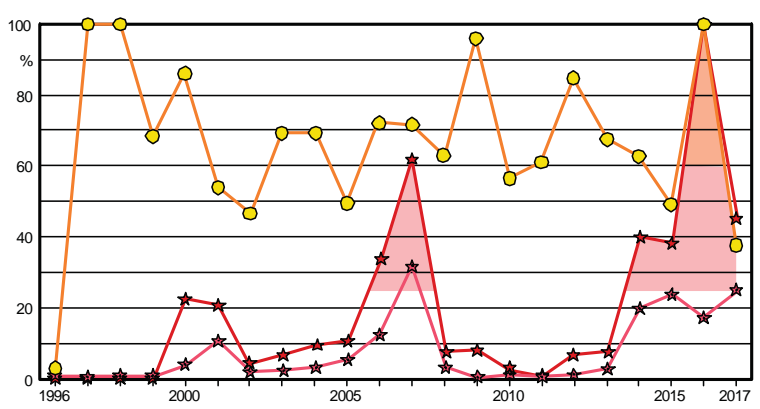

Ферровольфрам/Ferrotungsten

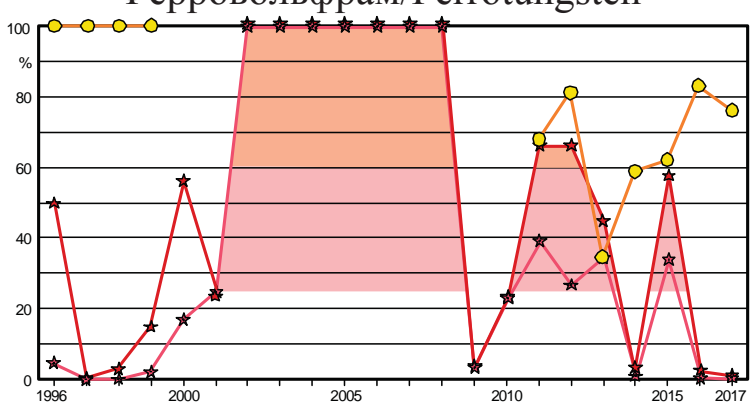

Паравольфрамат аммония+вольфрамовый ангидрит

Ammonium paratungstate+tungsten anhydrite

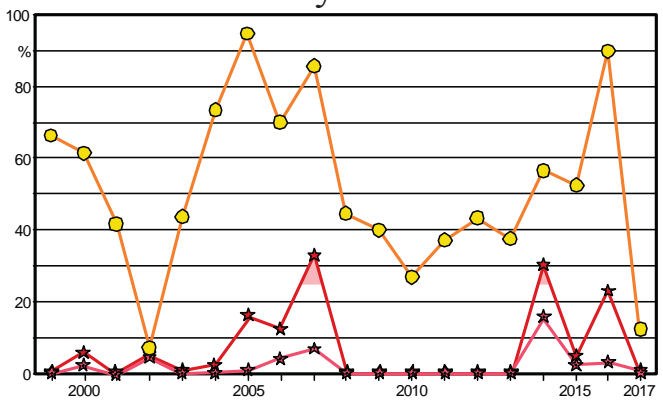

Вольфрам металлический/Metal tungsten

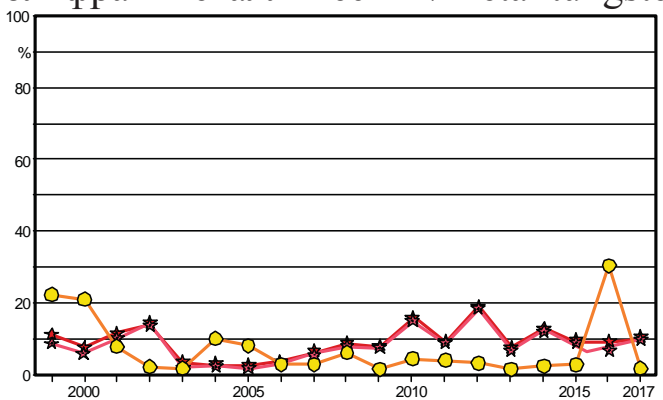

Рис. 5. Динамика долей илпорта и экспорта вольфрамовых продуктов в России за 1996-2017 г2. ‘ - доля илпорта от потребления, - доля илпорта от реализации (потребления+экспорта), О - доля экспорта от производства. Розовое поле - умеренная импортозависимость (25-60\%), коричневое - сильная илпортозависимость (>60\%)

Fig. 5. Dynamics of shares of import and export of tungsten products in Russia for 1996-2017. - share of imports from consumption, - share of imports from sales (consumption+exports), $\mathrm{O}$ - export share from production. Pink field is the moderate import dependence (25-60\%), brown field is the strong import dependence ( $>60 \%$ )

Импорт ПВА+ВА незначителен (максимум 0,55 тыс. т на сумму 23,1 млн \$США в 2014 г.) и эпизодичен. Поставки промпродуктов осуществляются из Китая, а в отдельные годы - из Вьетнама, Узбекистана, Нидерландов, США, Англии (рис. 3).

На мировом рынке имеет место увеличение продаж вольфраматов и вольфрамового ангидрита (10 тыс. т в 2017 г.) с темпами прироста $+4,0 \%$ /год. Значительная часть российского ПВА+ВА экспортируется, причем его объемы имеют значительные колебания во времени (от 0,2 до 2,7 тыс. т/год). Доля России в мировой торговле вольфраматами небольшая - 0,1-5,8 \%. В качестве покупателей выступают Нидерланды, Австрия, Чехия, Германия, Франция, Эстония и др. (рис. 3).

Динамика мировых цен на паравольфрамат аммония и вольфрамовый ангидрит (рис. 4) имеет временные тренды, схожие с динамикой цен на вольфрамовый концентрат: низкий стабильный уровень в период 1999-2004 гг., подъем цен в 2005-2006 гг. и стабилизация цен в 2006-2008 гг., снижение цен в 2009 г., новый резкий подъем в 2011 г. со стабилизацией цен в
2011-2014 гг. и последнее падение цен к локальному минимуму в 2016 г. Цены импорта промпродуктов в России вольфрамового концентрата в принципе близки к мировым, но цены экспорта на 20-30\% ниже мировых.

Исходя из динамики долей импорта и экспорта в 1999-2017 гг. паравольфрамат аммония и вольфрамовый ангидрит являются экспортоориентированными (рис. 5).

Динамика рынка ферровольфрама в России показана на рис. 2. Производство ферровольфрама крайне нестабильно и составляет первые сотни тонн в год. Российские предприятия по выпуску ферровольфрама (рис. 1):

- ПАО «Ключевской завод ферросплавов», г. Двуреченск, Свердловская область;

- 000 «Рязанский завод ферросплавов и лигатур", г. Рязань;

- ООО «Молирен», г. Рошаль, Московская область;

- 000 «Унечский завод тугоплавких металлов», г. Унеча, Брянская область;

- 000 «Предприятие «Кристалл», г. Кострома;

- 000 «Зубцовский машиностроительный завод», г. Зубцовск, Тверская область; 
- 000 «Промцветмет», г. Челябинск;

- 000 «Вишневогорский металлургический завод «Северный ниобий»», г. Екатеринбург.

Потребление же ферровольфрама российскими потребителями трудно оценить, но учитывая периодические импортные закупки до 1,1 тыс. т/год при одновременном экспорте до 2,7 до тыс. т/год он также составляет первые сотни тонн в год.

Поставки ферровольфрама по импорту осуществились из Казахстана, Эстонии, Германии, Китая, Латвии и др. (рис. 3). В 2014 г. в статистике Федеральной таможенной службы РФ [17] указывается значительная партия импорта ферровольфрама из Казахстана - 14,4 тыс. т на сумму 331 млн \$США, но этот транш не подтвержден в показателях экспорта в Таможенной службе Республики Казахстан [18]. Скорее всего, это результат переучета прежних поставок ферровольфрама и в проведенный баланс он не включен.

На экспорт же ферровольфрама поставляется значительно больше официального производства 0,4-2,7 тыс. т/год, что свидетельствует о неполных данных Госкомстата по его производству. По годам экспортные поставки этого продукта крайне неравномерны. Странами-покупателями ферровольфрама являются: Нидерланды, Латвия, Германия, Канада, Словакия, Китай и Эстония (рис. 3), т. е. и здесь появляются встречные импортно-экспортные потоки продукции. Формальный профицит импорта-экспорта на рынке ферровольфрама РФ не снимает проблемы его встречных потоков.

Динамика мировых цен на ферровольфрам коррелирует с динамикой мировых цен на вольфрамовые руды и концентраты и имеет следующие временные тренды (рис. 4): стабильный уровень 5500-6500 \$США/т в период 1996-2003 гг., подъем цен в 2004-2006 гг. и стабилизация на уровне 27 000-34 000 \$CША/т в 2006-2010 гг., новый подъем с историческим максимумом в $45000 \$ \mathrm{CША} /$ т в 2012 г. и падение до 21200 \$CША/т в 2017 г. Цены импорта в Россию ферровольфрама нестабильны - могут быть и больше и меньше мировых, а экспортные цены преимущественно на 20-40 \% ниже мировых.

Исходя из динамики долей импорта в 1996-2017 гг. ферровольфрам периодически попадает в область формальной импортозависимости (рис. 5), но в связи с неопределенностью объемов национального потребления эта категория для него весьма условна. По динамике долей экспорта ферровольфрама (большей частью его экспорт больше объемов национального производства), этот продукт также является экспортоориентированным товаром.

Максимальное внутреннее потребление вольфрамовых продуктов в России приходится на же таллический вольфрам, используемый для производства твердых сплавов.

Металлический вольфрам производят (рис. 1):

- ОАО «Победит», г. Владикавказ, Республика Северная Осетия;
- ОАО «Кировградский завод твердых сплавов», г. Кировоград, Свердловская область;

- 000 «Унечский завод тугоплавких металлов», г. Унеча, Брянская область;

- ОАО «Полема», г. Тула.

Всего ежегодно производится до 1,7 тыс. т металлического вольфрама, а также импортируется до 200 т/год (рис. 2). На мировом рынке имеет место увеличение продаж металлического вольфрама (24 тыс. т в 2017 г.) с темпами прироста $+5,6$ \% /год. Национальное потребление вольфрамовых твердых сплавов неравномерно во времени и составляет 1,0-1,7 тыс. т/год. Имеется небольшой рост потребления за период 1999-2017 гг. $+2,5 \%$ /год.

Импорт вольфрама металлического крайне мал и неравномерен во времени. Поставки осуществляются из Китая, Узбекистана, Германии, Нидерландов, Финляндии и др. (рис. 3).

На экспорт обычно поставляется всего до 0,05 тыс. т/год вольфрама металлического, лишь изредка происходит повышение до 0,3-0,4 тыс. т/год. Поставки осуществляются в Нидерланды, Германию, Украину, Эстонию, США и др. (рис. 3).

Динамика мировых цен на вольфрам металлический схожа с динамикой мировых цен на вольфрамовые руды, промпродукты и ферровольфрам и включает следующие временные тренды (рис. 4): стабильный уровень 12 500-18 000 \$CША/т в период 1996-2004 гг., подъем цен в 2005-2006 гг. и стабилизация на уровне $35000-37000 \$ C \amalg А /$ т в 2006-2009 гг., новый подъем до $65500 \$ \mathrm{CWA/т} \mathrm{в}$ 2011-2012 гг. и последующее падение до 40600 \$CША/т к 2017 г. Цены импорта и экспорта в Россию вольфрама металлического крайне нестабильны, в отдельных случаях на 40-60 \% выше мировых, а в 2016 г. - по чрезвычайно низким ценам, в 3 раза ниже мировых. Скорее всего, в учет таможенной статистики вольфрама необработанного попадают изделия из вольфрама и вольфрамовые отходы, что вызывает искажение сравниваемых цен.

Исходя из динамики долей импорта в 1996-2017 гг. имеющий существенно национальное потребление вольфрам металлический является импортонезависимым продуктом (рис. 5). Доля экспорта вольфрама металлического также мала.

На рис. 6 приведена динамика условной суммы товарооборота вольфрамовых продуктов в пересчете на $100 \%$ W в России за 1996-2017 гг., показывающая их экпортоориентированность (40-70\% от производства) и наличие критичного встречного импортного потока (до $40 \%$ ). Суммарно в товарообороте участвует 7-13 тыс. тW/год, с экспортным потоком 3,0-7,6 тыс. тW/год и импортным потоком $0,8-2,5$ тыс. тW/год.

По состоянию на 2017 г. на импорт приходится $46 \%$ от потребления вольфрамовых концентратов (1,47 тыс. т на сумму 13,8 млн \$США), 1 \% суммы паравольфрамата аммония + вольфрамового ангидрита $(0,02$ тыс. т на сумму 0,5 млн \$США), 0,3 \% 

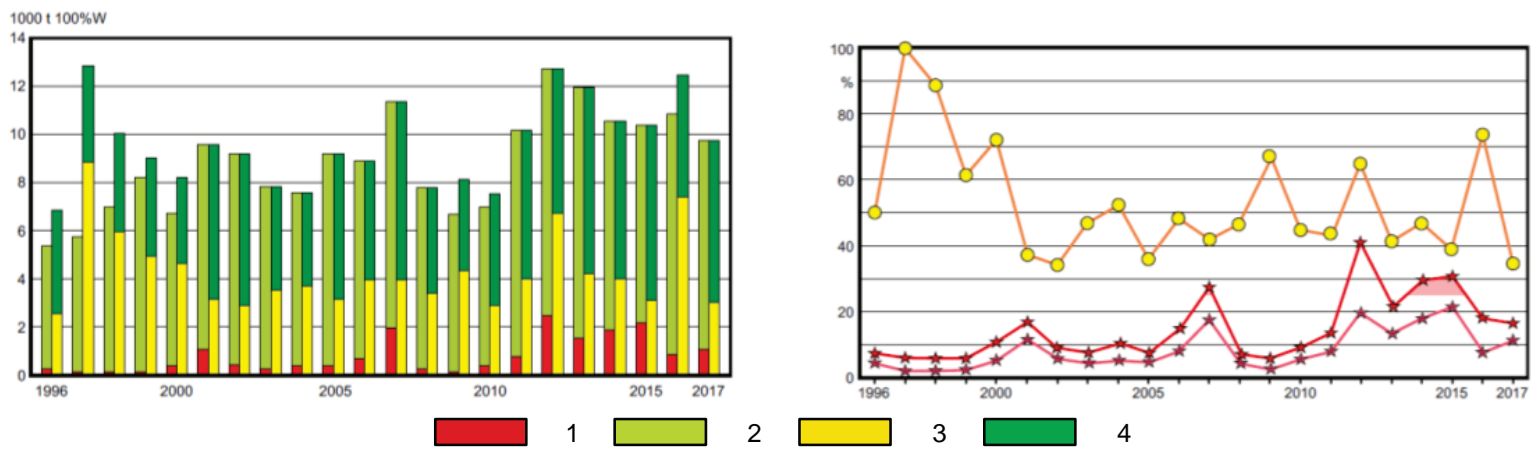

Pис. 6. Диналика рынка сулмы товарооборота вольфраловых продуктов в пересчете на вольфрал в России за 1996-2017 г2.: а) баланса рынка: 1 - илпорт, 2 - производство, 3 - экспорт, 4 - нетто-потребление; б) диналика долей илпорта и экспорта: $九$ - доля импорта от потребления, - доля импорта от реализащии (потребления + экспорта), О - доля экспорта от производства; розовое поле - умеренная илпортозависимость (свыше 25-60\%)

Fig. 6. Market dynamics of the total commodity circulation of tungsten products in terms of tungsten in Russia for 1996-2017: a) market balance: 1 - import, 2 - production, 3 - export, 4 - net consumption; $b$ ) dynamics of import and export shares: $\star$ - share of imports from consumption, - share of imports from sales (consumption + exports), $\mathrm{O}$ - share of export from production; pink field is the moderate import dependence (over $25 \%$ )

ферровольфрама (0,01 тыс. т на сумму $0,1 \mathrm{млн}$ \$США) и $3 \%$ вольфрама металлического (0,03 тыс. т на сумму 1,2 млн \$США). В целом по состоянию на 2017 г. суммарно вольфрамовые продукты в России являются потенциально импортозависимыми $(24,2 \%$ от потребления суммы вольфрамовых продуктов) [21, 22] и одновременно экспортоориентированными (исключая вольфрам металлический).

Для всех вольфрамовых продуктов наблюдаются встречные импортно-экспортные потоки (через Нидерланды, Германию Эстонию, Латвию, Англию), что свидетельствует о значительной доле торговли ими через трейдерские компании (Nordmet SA, C. Steinweg Handelsveem B.V., Scholz Recycling AG \& Co. KG и др. [11]). Наличие встречных потоков указывает на противоречие интересов добывающих, перерабатывающих и потребляющих вольфрамовую продукцию предприятий [23]. К тому же независимые трейдерские компании идут по наиболее легкому пути снижения цены на российские вольфрамовые продукты. Потоки российского экспорта и импорта для всех вольфрамовых продуктов характеризуются резкими скачками изменений, и по объемам, и по переменам торговых партнеров (рис. 3).

\section{Развитие вольфрамовой промышленности России}

Прогноз рынка потребления вольфраловой продукции российскими предприятиями осложняется внутренними и внешними факторами. Внутреннее потребление вольфрамовых концентратов (2,0-4,0 тыс. т/год) значительно меньше текущих объемов их национальной добычи $(5,5-7,0$ тыс. т/год), которые к тому же могут быть увеличены до 10 тыс. т/год. Производство ферровольфрама (до 2,5 тыс. т/год) было возобновлено в 2011 г., в условиях резкого роста мировых цен на этот продукт, но сконцентрировано оно преимущественно на переработке вторичного сырья, объем предло- жения которого ограничен. Использование ферровольфрама для производства жаропрочных и конструкционных сталей в России ограничено и колеблется в пределах 0,5-1,3 тыс. т/год. Основной объем национального потребления конечной вольфрамовой продукции приходится на металлический вольфрам и карбид вольфрама, используемые для изготовления быстрорежущего инструмента и буровых коронок, на уровне 1,0-1,5 тыс. т/год. Тенденции увеличения станочного парка и объемов разведочного бурения в России пока не проглядывается, и, скорее всего, объемы потребления карбида вольфрама останутся на том же уровне. На экспортное направление российских вольфрамовых продуктов оказывает давление сложившаяся ситуация избыточного предложения конкурентных производителей Китая, Германии и США. Это отчетливо видно в переменчивости состава российских контрагентов - покупателей вольфрамовой продукции. Экспорт 3,0-5,0 тыс. т/год вольррамовых концентратов, 1,0-2,5 тыс. т/год паравольфрамата аммония и вольфрамового ангидрита, до 2,5 тыс. т/год ферровольфрама и до 0,4 тыс. т/год металлического вольфрама нестабилен и во времени и по странам-покупателям. Их стабилизацию можно упорядочить, создав собственные российские трейдерские компании, ориентированные на поиск надежных и стабильных потребителей вольфрамовых продуктов. Импортные же потоки вольррамового сырья (до 3,0 тыс. т/год вольфрамовых концентратов и до 2,5 тыс. т/год ферровольфрама) являются нерациональными и в случае оздоровления российской вольфрамовой промышленности будут минимизированы.

В начале XXI в. в мире сложилась благоприятная обстановка для развития вольфрамовой промышленности. Бурный рост товарного производства (в первую очередь в Китае) способствовал резкому росту потребления вольфрамовых продуктов, а повышение цен на них - инвестиционной привлека- 
тельности вложений в проекты вольфрамовых производств. Реанимированы давно остановленные добывающие производства в Канаде (рудник Кантанг), Вьетнаме (рудник Нуи-Пхао) и Британии (проекты Ваймет, Мирекс и Хемердон) с созданием или реконструкцией на них перерабатывающих производств $[12,14]$. Впрочем, в последующей рецессии экономического кризиса 2009-2012 гг. канадское производство также легко было свернуто. Однако благоприятный инвестиционный период 2003-2008 гг. и благоприятное увеличение рынка потребления вольфрамовых продуктов в Германии (переход ее из экспортёров в нетто-импортеры этих товаров) в 2010-2017 гг. на состоянии российской вольфрамовой промышленности не отразились.

В целом же ситуация с российской вольфрамовой промышленностью продолжает оставаться неопределенной из-за отсутствия эффективной кооперации добывающих, перерабатывающих и потребляющих вольфрам производств, имеющих разнонаправленные интересы, а также внешнего воздействия, в зависимости от состояния мирового рынка вольфрамовой продукции.

Сходная ситуация нестабильности российской вольфрамовой промышленности имеет место также в других отраслях добывающей промышленности - кризисной оловянной (свертывание национальной добычи, тотальный экспорт оловянного концентрата и импорт металлического олова) и предкризисной борной (всего одно добывающее и перерабатывающие предприятие, встречные экспортные и импортные поставки буры и борной кислоты).

Следующие мероприятия могут улучшить ситуацию российского вольфрамового рынка:

1. Консолидацией предприятий, добывающих вольфраловое сырье, и перерабатывающих его предприятий в вертикально интегрированные холдинги. В качестве примера можно привести успешную интеграцию такой же проблемной российской молибденовой промышленности $\mathrm{AO}$ «УК «Союзметаллресурс», объединившей действующие компании, добывающие молибден, и новые ферромолибденовые производства [16]. Процесс объединения производств, добывающих и перерабатывающих вольфрамовое сырье, в интегрированные структуры уже ведется. ЗАО «Компания «Вольфрам» включает перерабатывающие вольфрамовое сырье мощности ОАО «Гидрометаллург», 000 «Унечский завод тугоплавких металлов», OAО «Победит» и подготавливаемые добывающие мощности 000 «Приморвольфрам». Этому холдингу требуется организовать интеграцию или кооперацию добывающих и перерабатывающих производства, а также создание собственных трейдерских компаний для управления торговлей вольфрамовыми продуктами как в России, так и за рубежом. Без формирования устойчивых товарных потоков постоянным потребителям товарных вольфрамовых продуктов их производство с позиции инвесторов будет оставаться высокорисковым. Та- ким же эффективным решением будет привлечение в вольфрамовую отрасль эффективных инвесторов. В качестве возможного решения возрождения Тырнаузского ГОКа является ресурсный проект 000 «РТ - Развитие бизнеса» Госкорпорации «Ростех» с объемом инвестиций 22,8 млрд р. [24].

2. Вовлечение в эксплуатацию новых воль фраловых месторождений. В настоящее время имеет смысл в первую очередь осваивать новые месторождения вольфрамовых руд со средним содержанием свыше $1 \% \mathrm{WO}_{3}$. $\mathrm{K}$ таким объектам можно отнести Агылкитское шеелитовое месторождение в Республике Саха (Якутия), которое включает запасы в 91 тыс. т $\mathrm{WO}_{3}$ при среднем содержании 1,271\% $\mathrm{WO}_{3}[16]$. Перспективы нахождения богатых вольфрамовых месторождений имеются на Гетканчикском рудном поле в Амурской области и на Иультинском рудном поле в Чукотском АО.

3. Реанилация закрытых добывающих производств на месторождениях с бедныли рудали на основе улучшения технологий обогащения. На территории России находится одно из крупнейших в мире Тырнаузское молибден-вольфрамовое месторождение с рядовыми рудами $\left(0,4 \% \mathrm{WO}_{3}\right)$, в настоящее время законсервированное. Рядом с ним находится еще одно крупное Кти-Тырнаузское вольфрамовое месторождение со средним содержанием $0,345 \% \mathrm{WO}_{3}$. Создание технологий обогащения, повышающих экономическую эффективность добычи вольррамового сырья из бедных руд [25, 26], позволило бы возродить Тырнаузский ГОК (проект $\mathrm{OOO}$ «РТ - Развитие бизнеса» Госкорпорации «Ростех») с созданием крупных по объемам поставок вольфрамовых руд, сопоставимых с мировыми производителями в Китае и Вьетнаме [24]. Здесь возможно развитие усовершенствования процессов рудоподготовки (крупнокусковое обогащение в тяжелых суспензиях), рентгенорадиометрического обогащения, снижения потерь металла с тонкими классами, использования новых флотационных реагентов [27, 28]. Аналогично, на основе внедрения новых технологий обогащения вольфрамовых руд, возможен пересмотр ресурсной базы Приморского ГОКа на месторождении Восток-2, где бедные руды списаны с баланса, а в отработке находятся только супербогатые руды со средним содержанием $4,4 \% \mathrm{WO}_{3}$.

Одной из новых особенностей мировой практики разработки вольфрамовых месторождений является ревизия старых месторождений, на которых вольфрам был лишь малоинтересным попутным компонентом или в результате селективной выработки остались только бедные руды. На этих объектах возобновляется производство вольфрамового сырья в Англии, Испании, Перу, Аргентине, Австралии [29, 30]. Возможна также ревизия (на предмет попутного вольфрама) известных оловянных месторождений в США, Мексике, Чили. Отмечается также наличие в технологических схемax многих новых проектов передела вольфрамовых концентратов в паравольфрамат аммония не- 
посредственно на месте их обогащения [31, 32]. Подобная практика успешно применена в смежной российской молибденовой промышленности - путем создания ферромолибденовых производств на Сорском и Жерикенском молибденовых рудниках $\mathrm{AO}$ «УК «Союзметаллресурс»» [16].

Еще один проект реанимации Джидинского вольфрамомолибденового комбината на базе Инкурского и Холтосонского месторождений в Республике Бурятия, включенный в перечень инвестиционных проектов Байкальского региона, осуществляет 000 «Тверосплав» (г. Чита). Он включает создание новых производственных участков, современной обогатительной фабрики и гидрометаллургического цеха по производству товарных вольфрамовых продуктов [16, 19].

В части промышленных способов переработки вольфрамового сырья также требуется внедрение новых технологий [28]:

- сплавление с сульфатом натрия и углем с образованием вольфрамата натрия или сульфосолей вольфрама;

- восстановительная плавка хвостов вольфрамового производства с добавлением в шихту $\mathrm{CaO}$ и $\mathrm{Fe}$ с образованием металлического расплава;

- хлорирование вольфрамового сырья с образованием летучих хлоридов и оксихлоридов вольфрама, которые легко разлагаются водой с образованием вольфрамовой кислоты;

- разложение вольфрамитовых концентратов растворами соды в автоклавах при повышенных температуре и давлении;

- спекание вольфрамитов с известью с целью превращения вольфрамита в шеелит с последующей его кислотной переработкой в паравольфрамат аммония;

- электролитическое восстановление вольфрамсодержащих продуктов и концентратов с получением металлического вольфрама технического качества;

- щелочное доизвлечение вольфрама из кеков кислотного разложения шеелитовых концентратов.

4. Государственные преферениии для вольфраловой пролышленности. Одной из причин кризиса российской вольфрамовой промышленности является пространственная отдаленность добывающих предприятий (на Дальнем Востоке) от перерабатывающих предприятий (в Европейской части России). Это приводит к дополнительным транспортным затратам при реализации вольфрамового сырья российским потребителям (увеличение себестоимости до $25 \%$ ) и становится более выгодно экспортировать полученную продукцию в Китай, Японию и Южную Корею (даже включая расходы на 10 \% экспортную таможенную пошлину). Государство имеет возможность регулировать железнодорожные тарифы для дальних перевозок вольфрамового сырья от российского производителя его российским потребителям (в настоящее время с повышающим коэффициентом 2,516), вводя понижающие тарифные коэффициенты, как, например, сделано для угля $(0,4)$ и калия хлористого $(0,139-0,1)$ [33]. В настоящее же время тарифные коэффициенты для руд цветных металлов самые высокие из всех перевозимых товарных продуктов.

Для проектов реанимации Тырнаузского ГОКа в Кабардино-Балкарской Республике и Джидинского ВМК в Республике Бурятия со стороны государства возможно стимулирование в виде временного обнуления ставки налога на добычу полезных ископаемых (для вольфрама $-8 \%$ от его реализации), как это сделано для кризисных предприятий по добыче оловянного сырья на Дальнем Востоке [34].

Государственные органы в рамках своей компетенции осуществляют координацию действий исполнительной власти с участием заинтересованных хозяйствующих компаний и организаций в планировании мероприятий по импортозамещению. Так, ОАО «Победит» и ОАО «Кировоградский завод твердых сплавов» совместно с Государственной корпорацией «Ростех» участвуют в программе импортозамещения в станкоинструментальной промышленности в России [35], которая сопровождается различными мерами стимулирования и государственной поддержки реализации этих проектов.

\section{Выводы}

1. Российская вольфрамовая промышленность преимущественно ориентирована на экспорт по вольфрамовому концентрату (50-100\%), вольфраматам (40-90\%) и ферровольфраму (35-100\%). Является лидером мировой торговли вольфрамовых концентратов (12-31 \% мирового рынка), но в то же время она утрачивает свои позиции на мировом рынке вольфрамовых продуктов. Лидеры мирового производства вольфрама (Китай и Вьетнам) наращивают добычу вольфрамового сырья, причем полностью перерабатывают его на вольфрамовые продукты с большей прибавочной стоимостью.

2. Россия обладает достаточной сырьевой базой для обеспечения вольфрамовой продукцией национальных потребителей и поставок на экспорт. Расширение объемов производства возможно за счет возобновления добычных работ на Тырнаузском ГОКе в Кабардино-Балкарской Республике (проект 000 «РТ - Развитие бизнеса» Госкорпорации «Ростех») и Джидинском ВМК в Республике Бурятия (проект 000 «Тверосплав»), а также осуществления нового добывающего проекта на Агылкитском месторождении в Республике Саха (Якутия).

3. Российский рынок вольфрама вследствие влияния внешних причин (цены и сбыт опосредовано вытекают из действий китайских производителей вольфрамовой продукции) разупорядочен и осложняется несогласованностью интересов добывающих, перерабатывающих и потре- 
бляющих вольфрамовую продукцию предприятий. В результате этого возникли встречные импортно-экспортные потоки вольфрамовых концентратов (импорт до $39 \%$ от потребления), паравольфрамата аммония (до $30 \%$ ), ферровольфрама (до $66 \%$ ) и вольррама металлического (до $30 \%$ ).

4. Для оздоровления российской вольфрамовой промышленности необходима консолидация добывающих вольфрамовое сырье и перерабатывающих предприятий в вертикально интегрированные холдинги, привлечение в вольфрамовую отрасль состоятельных инвесторов, реанимация закрытых добывающих производств на крупных и уникальных месторождениях с бедными рудами на основе улучшения технологий обогащения, поиски и освоение новых месторождений с богатыми вольфрамовыми рудами, создание производств с полным циклом переработки вольфрамового сырья с реализацией товарных вольфрамовых продуктов с высокой прибавочной стоимостью. Участие

\section{СПИСОК ЛИТЕРАТУРЫ}

1. Александров П.В., Петров И.М., Гришаев С.И. Тенденции развития мирового и российского рынков вольфрама // Минеральные ресурсы России. Экономика и управление. - 2012. № 2. - C. $66-69$.

2. Локальное прогнозирование плутоногенных месторождений молибдена, вольфрама и олова / Ф.Р. Апельцин, С.Ф. Лугов, В.Т. Покалов, А.А. Фролов. - М.: Недра, 1985. - 244 с.

3. Денисенко В.К. Месторождения вольфрама. - М.: Недра, 1978. - 143 c.

4. Повилайтис М.М. Закономерности размещения и формирования месторождений вольфрама. - М.: Наука, 1975. - 255 с.

5. Werner A.B.T., Sinclair W.D., Amey E.B. International strategic mineral issues summary report. Tungsten. U.S. Geological Survey. - November 2014. - 86 p. URL: https://pubs.er. usgs.gov/publication/cir9300 (дата обращения: 12.11.2018).

6. Zafirov B. The strategic challenges on world tungsten market // International Journal on Information Technologies and Security. - 2010. - № 3. - P. 69-80.

7. World Tungsten Report. Metal-Pages Ltd. - November 2013. 12 p. URL: https://minerals.usgs.gov/minerals/pubs/commodity/tungsten/myb1-2013-tungs.pdf (дата обращения: 12.11.2018)

8. Anstett T.F., Bleiwas D.I., Hurdelbrink, R.J. Tungsten availability - market economy countries. A minerals availability program appraisal // Information Circular. - Pittsburgh: US Bureau of Mines, $1985 .-51 \mathrm{p}$.

9. Brookes K.J.A. Tungsten targets munitions market // Metal Powder Report. - 1999. - V. 54. - № 10. - P. 16-19.

10. Geology, geochemistry, and genesis of tungsten-tin deposits in the Baiganhu District, Northern Kunlun Belt, Northwestern China / Y. Gao, W. Li, Z. Li, J. Wang, K. Hattori, Z. Zhang, J. Geng // Economic Geology. - 2014. - V. 109. - № 6. - P. 1787-1799.

11. Shedd K.B. Tungsten. [Advance Release]. 2015 Minerals Yearbook. U.S. Geological Survey. - November 2014. - 22 p. URL: https:// minerals.usgs.gov/minerals/pubs/commodity/tungsten/ myb1-2015-tungs.pdf (дата обращения: 12.11.2018).

12. Global tungsten demand and supply forecast / J. Dvorácek, R. Sousedíková, T. Vrátný, Z. Jureková // Archives of Mining Sciences. - 2017. - V. 62. - № 1. - P. 3-12. DOI: 10.1515/amsc2017-0001.
Госкорпорации «Ростех» в проектах реконструкции Тырнаузского ГОКа и предприятий производства твердых сплавов может исправить ситуацию нестабильности вольфрамовой отрасли.

5. Со стороны государства возможно содействие в «оздоровлении» российской вольфрамовой промышленности в части поддержки инфраструктурных проектов и стимулирования импортозамещения, а также регулирования железнодорожных тарифов на перевозку вольфрамового сырья от российского производителя его российским потребителям. Уменьшение железнодорожных тарифов на вольфрамовый концентрат (по аналогии с пониженными тарифами для угля и калийных солей) может решить проблему невыгодности поставок дальневосточного сырья на перерабатывающие предприятия в европейской части России и уменьшить вынужденный экспорт вольфрамового концентрата в азиатском направлении по ценам ниже мировых.

13. Focus on some aspects of market price trends for tungsten / J. Dvořacek, R. Sousedíkova, A. Krzemien, A.S. Sanchez // Acta Montanistica Slovaca. - 2017. - V. 22. - № 2. - P. 126-135.

14. U.S. Geological Survey. URL: http://minerals.usgs.gov/minerals/pubs/commodity/tin/index.html\#mcs (дата обращения 12.11.2018).

15. Minerals UK. URL: http://www.bgs.ac.uk/mineralsuk/statistics/worldStatistics.html (дата обращения 12.11.2018).

16. Государственный доклад «0 состоянии и использовании минерально-сырьевых ресурсов Российской Федерации в 2016-2017 годах». URL: http://www.mnr.gov.ru/docs/o_sostoyanii i ispolzovanii mineralno syrevykh resursov rossiyskoy_federatsii/gosudarstvennyy_doklad_0_sostoyanii_i_ispolzovanii_mineralno_syrevykh_resursov_rossiyskoy_federatsii/ (дата обращения 12.11.2018).

17. Федеральная таможенная служба России. URL: http://stat. customs.ru/analytics/ (дата обращения: 12.11.2018).

18. Kazdata. Маркетинговый бизнес-справочник Казахстана. URL: https://kazdata.kz/ (дата обращения: 20.01.2018).

19. Обзор рынка вольфрама в СНГ. 12 изд. - М.: ИГ «Инфомайн», 2017. - $274 \mathrm{c}$.

20. Международная торговля товарами. TrendEconomy. URL: http://data.trendeconomy.ru/dataviewer/trade/statistics/ (дата обращения 12.11.2018).

21. Хатьков В.Ю., Боярко Г.Ю. Регулирование импорта дефицитного для России минерального сырья // Горный журнал. 2005. - № 9-10. - С. 53-56.

22. Хатьков В.Ю. 0 товарных потоках импортозависимых минеральных продуктов // Минеральные ресурсы России. Экономика и управление. - 2017. - № 5. - С. 66-71.

23. Хатьков В.Ю., Боярко Г.Ю. Мировые и российские встречные импортно-экспортные потоки минерального сырья // Известия Томского политехнического университета. Инжиниринг георесурсов. -2018 . - № 3. - С. 145-167.

24. Государственная корпорация «Ростех». Годовой отчет за 2017 год. Партнер в развитии. 10 лет устойчивого роста. - М.: Ростех, 2018. - 131 c. URL: https://rostec.ru/upload/iblock/609/60954456d3f675625e60918653ceb028.pdf (дата обращения 26.11.2018).

25. Саматова Л.А., Шепета Е.Д., Алушкин И.В. Перспективы внедрения әффективных методов рудоподготовки в технологиях 
переработки бедных вольфрамовых руд // Горный информационно-аналитический бюллетень. - 2016. - № S21. C. $316-327$.

26. Хантургаева Г.И. Комбинированные технологии комплексной переработки труднообогатимых молибденовых и вольфрамовых руд // Горный информационно-аналитический бюллетень. - 2009. - Т. 14. - № 12. - С. 478-494.

27. Бутуханов В.Л., Хромцова Е.В. Изучение условий получения кондиционных вольфрамовых концентратов Лермонтовского месторождения // Вестник Тихоокеанского государственного университета. - 2015. - № 2 (37). - С. 73-78.

28. Иванков С.И., Литвинцев Э.Г., Петкевич Д.Г. Проблемы создания современных экологически малонапряженных технологий переработки комплексных вольфрамовых руд и пути их решения // Научные и технические аспекты охраны окружающей среды. Обзорная информация. - М.: Изд-во ВИНИТИ, 2013. - Вып. 3. - С. 1-138.

29. Investment in new tungsten mining projects / S.A. Suarez, A. Krzemien, F.P. Riesgo, R.F.J. Iglesias, L.F. Sanchez, J.F.J. de Cos // Resources Policy. - 2015. - V. 46. - P. 177-190. DOI: $10.1016 /$ j.resourpol.2015.10.003.

30. Beyond the pan-European standard for reporting of exploration results, mineral resources and reserves / A. Krzemien, F.P. Riesgo, S.A. Suarez, A.I. Diego // Resources Policy. - 2016. V. 49. - P. 81-91. DOI: 10.1016/j.resourpol.2016.04.008.
31. Singh G.R.P. Modern hydrometallurgical production methods for tungsten // Journal of Metals. - 2006. - V. 58. - № 9. P. 45-49.

32. Gaur R.P.S. Modern methods of hydrometallurgical production of ammonium paratungstate (APT) // Proc. of the $8^{\text {th }}$ International Conference on Tungsten, Refractory and Hardmaterials 2011. - San Francisco, CA, United States, 18-21 May 2011. P. 21-216.

33. Прейскурант N 10-01 «Тарифы на перевозки грузов и услуги инфраструктуры, выполняемые российскими железными дорогами» // Постановление Федеральной энергетической комиссии РФ от 17.06.2003 № 47-т/5 (ред. от 05.09.2017). «Бюллетень нормативных актов федеральных органов исполнительной власти» (приложение к № 30, 28.07.2003).

34. Боярко Г.Ю., Хатьков В.Ю. Мировой рынок олова и современное состояние оловянной промышленности России // Цветные металлы. - 2018. - № 1. - С. 47-55.

35. План мероприятий по импортозамещению в станкоинструментальной промышленности Российской Федерации. Утвержден Приказом Министерства промышленности и торговли РФ от 31 марта 2015 г. N 650.

\section{Информация об авторах}

Хатьков В.Ю., начальник департамента 817 ПАО «Газпром»; соискатель нефтегазового отделения Инженерной школы природных ресурсов Национального исследовательского Томского политехнического университета.

Боярко Г.Ю., доктор экономических наук, кандидат геолого-минералогических наук, профессор отделения нефтегазового дела Инженерной школы природных ресурсов Национального исследовательского Томского политехнического университета. 


\title{
CURRENT STATE OF TUNGSTEN INDUSTRY IN RUSSIA
}

\author{
Vitaly Yu. Khatkov ${ }^{1,2}$, \\ vitaliy@payler.com \\ Grigory Yu. Boyarko², \\ gub@tpu.ru \\ 1 Gazprom, \\ 2, Pobedy square, St. Petersburg, 196143, Russia. \\ ${ }^{2}$ National Research Tomsk Polytechnic University, \\ 30, Lenin Avenue, Tomsk, 634050, Russia.
}

The relevance of the work is caused by the need to study the problems of the Russian tungsten industry.

The aim of this research is to study the dynamics of commodity flows (production, import, export, consumption) of tungsten products (tungsten concentrates, ammonium paratungstate, tungsten anhydrite, ferrotungsten and metal tungsten); to develop recommendations for optimizing the turnover of tungsten products.

Research methods: statistical, graphic, logical.

Results. Russia has a sufficient raw material base to provide tungsten products to national consumers and exports. Resumption on Tyrnyauzsky mining and processing plant in the Kabardino-Balkar Republic, Jedin tungsten-molybdenum combine in the Republic of Buryatia and implementation of a new production project in Agylkynskoe mine in the Republic of Sakha (Yakutia) is possible. Russian tungsten raw materials market is subject to sharp fluctuations in production, export and import volumes, complicated by the lack of coordination of interests of mining, processing and consuming tungsten products enterprises. In addition to reducing the production of tungsten raw materials due to the stop of loss-making mines the counter import-export flows of tungsten concentrates, ammonium paratungstate and ferrotungsten appeared. These flows formed the dependence on imports for their consumers. To recover Russian tungsten industry, it is necessary to consolidate enterprises, extracting tungsten raw materials and processing enterprises into vertically integrated holdings with the involvement of wealthy investors, the resuscitation of closed mining operations in large and unique fields with poor ores on the basis of improving enrichment technologies, search and development of new fields with rich tungsten ores. On the part of the state, it is possible to assist in improvement of the Russian tungsten industry in terms of supporting infrastructure projects and stimulating import substitution, as well as regulating railway tariffs for tungsten raw material transportation from Russian manufacturer to its Russian consumers.

\section{Key words:}

Tungsten industry in Russia, tungsten concentrates, ammonium paratungstate, tungsten dioxide, ferrotungsten, metal tungsten, artificial dependence on imports.

\section{REFERENCES}

1. Aleksandrov P.V., Petrov I.M., Grishaev S.I. Trends in development of the world and Russian tungsten markets. Mineralnye resursy Rossii. Ekonomika i upravlenie, 2012, no. 2, pp. 66-69. In Rus.

2. Apeltsin F.R., Lugov S.F., Pokalov V.T., Frolov A.A. Lokalnoe prognozirovanie plutonogennykh mestorozhdeniy molibdena, volframa i olova [Local prediction of plutogenic deposits of molybdenum, tungsten and tin]. Moscow, Nedra Publ., 1985. 244 p.

3. Denisenko V.K. Mestorozhdeniya volframa [Tungsten deposits]. Moscow, Nedra Publ., 1978. 143 p.

4. Povilaytis M.M. Zakonomernosti razmeshcheniya i formirovaniya mestorozhdeniy volframa [Patterns of placement and formation of tungsten deposits]. Moscow, Nauka Publ., 1975. 255 p.

5. Werner A.B.T., Sinclair W.D., Amey E.B. International strategic mineral issues summary report. Tungsten. U.S. Geological Survey. November 2014. 86 p. Available at: https://pubs.er. usgs.gov/publication/cir9300 (accessed 12 November 2018).

6. Zafirov B. The strategic challenges on world tungsten market. In ternational Journal on Information Technologies and Security, 2010, no. 3, pp. 69-80.

7. World Tungsten Report. Metal-Pages Ltd. November $2013.12 \mathrm{p}$ Available at: https://minerals.usgs.gov/minerals/pubs/commodity/tungsten/myb1-2013-tungs.pdf (accessed 12 November 2018).

8. Anstett T.F., Bleiwas D.I., Hurdelbrink, R.J. Tungsten availability - market economy countries. A minerals availability program appraisal. Information Circular. Pittsburgh, US Bureau of Mines, $1985.51 \mathrm{p}$.

9. Brookes K.J.A. Tungsten targets munitions market. Metal Powder Report, 1999, vol. 54, no. 10, pp. 16-19.

10. Gao Y., Li W., Li Z., Wang J., Hattori K., Zhang Z., Geng J. Geology, geochemistry, and genesis of tungsten-tin deposits in the Baiganhu District, Northern Kunlun Belt, Northwestern China. Economic Geology, 2014, vol. 109, no. 6, pp. 1787-1799.

11. Shedd K.B. Tungsten. [Advance Release]. 2015 Minerals Yearbook. U.S. Geological Survey. November 2014. 22 p. Available at: https://minerals.usgs.gov/minerals/pubs/commodity/tungsten/myb1-2015-tungs.pdf (accessed: 12 November 2018).

12. Dvořácek J., Sousedíková R., Vrátný T., Jureková Z. Global tungsten demand and supply forecast. Archives of Mining Sciences, 2017, vol. 62, no. 1, pp. 3-12. D0I: 10.1515/amsc-2017-0001.

13. Dvořacek J., Sousedíkova R., Krzemien A., Sanchez A.S. Focus on some aspects of market price trends for tungsten. Acta Montanistica Slovaca, 2017, vol. 22, no. 2, pp. 126-135.

14. U.S. Geological Survey. Available at: http://minerals.usgs.gov/ minerals/pubs/commodity/tin/index.html\#mcs (accessed: 12 November 2018).

15. British Geological Survey (BGS). Available at: http://www. bgs.ac.uk/mineralsuk/statistics/worldStatistics.html (accessed: 12 November 2018).

16. Gosudarstvenny doklad «0 sostoyanii i ispolzovanii mineralno-syrevykh resursov Rossiyskoy Federatsii v 2016-2017 godu» [State report «0n the state and use of mineral resources of the Russian 
Federation in 2016-2017»] Available at: http://www.mnr.gov. $\mathrm{ru} /$ docs/o sostoyanii i ispolzovanii mineralno syrevykh resursov_rossiyskoy_federatsii/gosudarstvennyy_doklad_o_sostoyanii_i_ispolzovanii_mineralno_syrevykh_resursov_rossiyskoy_federatsii/ (accessed: 12 November 2018).

17. Federalnaya tamozhennaya sluzhba Rossii [Federal Customs Service Russian Federation]. Available at: http://stat.customs.ru/ analytics/ (accessed: 12 November 2018).

18. Kazdata. Marketingovy biznes-spravochnik Kazahstana [Marketing business directory of Kazakhstan]. Available at: https://kazdata.kz/ (accessed: 20 January 2018).

19. Obzor rynka volframa $v S N G$ [Overview of the tungsten market in the CIS]. Moscow, Infomayn, 2017. 274 p.

20. TrendEconomy. Available at: http://data.trendeconomy.ru/dataviewer/trade/statistics/ (accessed: 12 November 2018).

21. Khatkov V.Yu., Boyarko G.Yu. Regulirovanie importa deficitnogo dlya Rossii mineralnogo syrya [Import regulation for minera] raw materials that are lacking in Russia]. Gorny zhurnal, 2005, no. 9-10, pp. 53-56.

22. Khatkov V.Yu. About commodity flows of import-dependent mineral products. Mineralnye resursy Rossii. Ekonomika i upravlenie, 2017, no. 5, pp. 66-71. In Rus.

23. Khatkov V.Yu., Boyarko G.Yu. World and Russian counter import/export flows of mineral products. Bulletin of the Tomsk Polytechnic University. Geo assets Engineering, 2018, vol. 329, no. 3, pp. 145-167. In Rus.

24. Gosudarstvennaya korporatsiya «Rostekh». Godovoy otchet za 2017 god. Partner v razuitii. 10 let ustoychivogo rosta [State Corporation «Rostec». Annual report 2017. Partner in development. 10 years of sustainable growth]. Moscow, Rostekh, 2018. 131 p. Available at: https://rostec.ru/upload/iblock/609/60954456d3f 675625e60918653ceb028.pdf (accessed: 26 November 2018).

25. Samatova L.A., Shepeta E.D., Alushkin I.V. Prospects of introduction of the efficient techniques of ore preparation in processing of tungsten poor ores. Gorny informatsionno-analiticheskiy byulleten, 2016, no. S21, pp. 316-327. In Rus.

26. Khanturgaeva G.I. Combined technologies of complex processing of difficult-to-enrich molybdenum and tungsten ores. Gorny in formatsionno-analiticheskiy byulleten, 2009, vol. 14, no. 12 , pp. 478-494. In Rus.

27. Butukhanov V.L., Khromtsova E.V. Study of conditions of producing certified tungsten concentrates of Lermontovski deposits. Vestnik Tikhookeanskogo gosudarstvennogo universiteta, 2015, no. 2 (37), pp. 73-78. In Rus.
28. Ivankov S.I., Litvintsev E.G., Petkevich D.G. Problemy sozdaniya sovremennykh ekologicheski malonapryazhennykh tekhnologiy pererabotki kompleksnykh volframovykh rud i puti ikh resheniya [Problems of developing modern environmentally low-stress technologies of processing complex tungsten ores and ways of their solution]. Nauchnye $i$ tekhnicheskie aspekty okhrany okruzhayushchey sredy. Obzornaya informatsiya [Scientific and technical aspects of saving the environment. Review]. Moscow, VINITI Publ., 2013. Iss. 3, 138 p.

29. Suarez S.A., Krzemien A., Riesgo F.P., Iglesias Rodriguez F.J., Sanchez L.F., de Cos J.F.J. Investment in new tungsten mining projects. Resources Policy, 2015, vol. 46, pp. 177-190. DOI: 10.1016/j.resourpol.2015.10.003.

30. Krzemien A., Riesgo F.P., Suarez S.A., Diego A.I. Beyond the pan-European standard for reporting of exploration results, mineral resources and reserves. Resources Policy, 2016, vol. 49, pp. 81-91. DOI: 10.1016/j.resourpol.2016.04.008.

31. Singh G.R.P. Modern hydrometallurgical production methods for tungsten. Journal of Metals, 2006, vol. 58, no. 9, pp. 45-49.

32. Gaur R.P.S. Modern methods of hydrometallurgical production of ammonium paratungstate (APT). Proc. of the $8^{\text {th }}$ International Conference on Tungsten, Refractory and Hardmaterials 2011. San Francisco, CA, United States, 18-21 May 2011. pp. 21-216.

33. Preyskurant N 10-01 «Tarify na perevozki gruzov i uslugi infrastruktury, vypolnyaemye rossiyskimi zheleznymi dorogami" [Price list N 10-01 «Tariffs for transportation of goods and infrastructure services performed by Russian Railways»]. Postanovlenie Federalnoy energeticheskoy komissii RF ot 17.06.2003 N 47-t/5 (red. ot 05.09.2017) [RF Federal Energy Commission order no. 47-t/5, 17.06.2003]. Byulleten normativnykh aktov federalnykh organov ispolnitelnoy vlasti (prilozhenie $\mathrm{k}$ № 30 , 28.07.2003). [Bulletin of standard acts of Federal executive authority].

34. Boyarko G.Yu., Khatkov V.Yu. Global market of tin and modern state of tin industry in Russia. Tsvetnye metally, 2018, no. 1, pp. 47-55. In Rus. DOI: 10.17580/tsm.2018.01.06.

35. Plan meropriyatiy po importozameshcheniyu v stankoinstrumentalnoy promyshlennosti Rossiyskoy Federatsii [Plan of measures for import substitution in the machine tool industry of the Russian Federation]. Utverzhden Prikazom Ministerstva promyshlennosti i torgouli RF. 31 Marta $2015 \mathrm{~g}$. N 650 [Approved by the order of the Ministry of Industry and Trade of the RF, 31.03.2015, no. 650].

Received: 22 December 2018.

\section{Information about the authors}

Vitaly Yu. Khatkov, head of the Department, Gazprom; postgraduate student, National Research Tomsk Polytechnic University.

Grigory Yu. Boyarko, Dr. Sc., Cand. Sc., professor National Research Tomsk Polytechnic University. 